\title{
Quality Assessment and Process Management of Welded Joints in Metal Construction-A Review
}

\author{
António B. Pereira *(1) and Francisco J. M. Q. de Melo \\ TEMA-Centre of Mechanical Technology and Automation, Department of Mechanical Engineering, \\ University of Aveiro, 3810-193 Aveiro, Portugal; francisco@ua.pt \\ * Correspondence: abastos@ua.pt; Tel.: +351-234-370-830
}

Received: 14 December 2019; Accepted: 9 January 2020; Published: 12 January 2020

\begin{abstract}
This paper aims to express the maturity and dynamism of welding in industry. It follows the direct observation of international construction standards and rules, here described as an introduction to the most relevant themes in the area of welding processes. Quality management in welded construction involves well-regulated procedures which are, however, so vast that they are of great complexity. In fact, there are hundreds of rules to apply to each specific case. This makes it imperative to have a welding coordinator, at least in cases of greater responsibility. In fact, the application of the rules presents yet another difficulty: along with the breadth of the rules, each country may adopt certain special requirements in their own case. Thus, it is essential to know the necessary path for the proper development of responsible work. First, one must know the various welding processes, their advantages and limitations; then one must identify the regulations applicable to the work concerned; and finally, one must know what tests and qualifications are required, including the expected defects and acceptance criteria. One purpose of this work is to show the necessary path for the implementation of a welding quality management system in metal construction, as well as to present the numerous applicable norms, both for the welder and the welding coordinator, but also for the process and the product. This paper also presents an analysis of how to obtain the CE marking (Conformité Européene) for a welded metal construction and which normative ramifications apply.
\end{abstract}

Keywords: welding; welding quality; welding management; welding standards; CE marking in welded structures

\section{Introduction}

Nowadays, there are more than 100 standardized welding and allied processes, with each one requiring its own expertise in specific cases. Despite the superposition of common suitability fields among such cases, sometimes less obvious selections are required for each application.

With respect to welding methods and standards specifications, which govern welding processes side by side, it is possible to find a huge amount of documentation regarding this technology from all around the world. In addition, international standards (namely, European and North American standards), in addition to Japanese standards, are widely applied in welding engineering. In fact, each country may develop their own particular rules and standards, making the certification of international projects more complex. However, the aim of this paper is not to argue about the quantity of regulatory specifications; rather, it is necessary to devote major attention towards the updating of standards, which will sometime lead to imperative change in the process rules.

Despite some welding processes having existed for a long time, efforts in their development are still being carried out in order to make them safer and more energy efficient. For example, recent methods of current inversion technology and the use of microprocessor controller technologies have resulted in new alternatives for old-fashioned methods, such as, for example, manual metal arc 
welding and TIG (Tungsten Inert Gas) welding techniques, among others. In the field of pulsed laser applications with high peak power levels, dozens of KW of welding power is available in machines that cost less than $40,000 €$.

With the recent implementation of European legislation, mandatory rules apply not only to the operator welding process, but also to the engineer's supervision of welding procedures.

Welding is a part-joining process wherein two or more components are connected by heat application, pressure, or both, typically with the use of an additional material [1].

In a good quality welded joint, the mechanical properties of the joint must be equal to or better than those of the base material. In practice, welded joints show continuity at the atomic level with the parts to be joined; however, presenting some alterations are present in the microstructure in the connection zone.

The ISO 25901 standard contains ten parts, containing the technical weld glossary. Part 1 contains general terms regarding welding and allied processes. In Part 2, definitions are presented regarding safety procedures and health. Parts 3 to 10 refer to welding processes and their specific vocabulary. In 2019, several parts were still in development [1].

The welding process is subordinate to standards in practically all of its aspects, since its prerequisites include working personnel, equipment, consumable items, conditions of testing, etc.

In Europe, EN, European Standards, and ISO, the International Organization for Standardization, are frequently used, but so are AWS, the American Welding Society, and ASME, the American Society of Mechanical Engineers. Not all European Standards follow ISO recommendations, and vice-versa, although there is a trend for harmonization being carried out. In turn, AWS specifications are frequently very similar to ISO specifications, while presenting significant differences both with respect to their format and their contents, grade of exigency, etc. Conversely, AWS and ASME complement each other, in essence. There is therefore an obligation to indicate which standard governs the scope of the welding project.

In Europe, welding process designations essentially adopt the contents of ISO 4063 [2], and their identification by numbers as included in the Standards (e.g., the standard indication No. 111-Manual Metal Arc Welding (MMA)). AWS A3.0 [3] is the standard used in the USA.

The standardization of welding processes and procedures is primarily implemented for safety reasons. In fact, the failure of an in-service weld can lead to a catastrophic event; therefore, quality assessment in welding is of the outmost importance. Thus, numerous authors have studied and developed welding analysis and correction processes during welding process execution, while also analyzing the management of welding-related operations.

Stavridis et al. [4] implemented a way of identifying and evaluating the quality of laser weld beads. Their work introduced a cognitive assessment method for the prediction of weld quality and classification into different quality categories. The study incorporated camera-based monitoring approaches, utilizing thermal images obtained from process simulation models where artificial defects were inserted. A dimensionality reduction technique was deployed; subsequently, an image processing technique was implemented to identify weld defects based on specific melt pool features. The requirements and specifications of a unified quality diagnosis platform for laser processing based on dimensionality reduction, machine learning, and statistical techniques for overall stitch quality status were discussed and presented.

Summerville et al. [5] investigated four commonly used weld quality testing protocols for resistance spot weld quality assessment: tensile shear, a chisel test, ultrasonic inspection and peel strength testing. They presented a range of spot-welding data to demonstrate the variability of the results and assess the correlation between nugget diameter (the industry standard) and the strength of the joint. Their study highlights the benefits and limitations of each quality assessment technique, and the limitations associated with using one metric to infer the outcome of another. Comparisons were made between the industry standard, the measurement of weld nugget diameter, and each additional testing protocol. They concluded that the quality of resistance spot welds was inherently difficult to measure 
and quantify, and that the most common non-destructive quality testing technique used in industry, ultrasound, was not strongly correlated with button diameter, especially under difficult situations; therefore, it was concluded that spot weld button diameter did not necessarily adequately characterize joint quality.

Szeleziński et al. [6] described a methodology and the required scientific apparatus to register dynamic characteristics in the case of continuous monitoring systems of welded joints of thin-walled structures. The most important advantage of the vibrodiagnostic method is that it is effective and offers the greatest real-time research capabilities. These authors presented a measurement method of dynamic characteristics of the structure with the use of piezoelectric sensors. They used the analysis of the mean value distribution of the amplitude spectrums calculated by the time window method, and the statistical measure used in the form of the mean value is a proposed parameter. The results of their tests indicated that the analysis of the distribution of mean values for amplitude spectra calculated by the time window method differed markedly depending on the welds, indicating their quality and the defects that were associated with them.

Stavridis et al. [7] presented relevant studies regarding quality assessment methods and techniques for inspection on laser welding, namely, image processing, acoustic emissions, $\mathrm{x}$-ray, and eddy current. Furthermore, they mapped the existing modeling approaches used for correlating measured weld characteristics and defects with the process parameters. They concluded that for in-process quality assessment techniques, non-invasive optical sensing could be considered to be the ideal real-time monitoring technology for laser welding.

Stenberg et al. [8] presented a comprehensive overview of weld quality control and assurance of welded structures where the major failure prevention is due to fatigue loading. They descrubed the drawbacks and limitation of quality control systems, international weld quality standards, and the guidelines used in today's weld production. The information gathered can be used for determining the weld quality level with respect to the fatigue strength but also to improve process control. They verified that the new online method, a new laser scanning technology, and algorithms could successfully be used as modern tools for automated unbiased geometrical weld quality assurance and implemented in weld production environment. A new system has been developed, ONWELD (Online method for quality assurance of welded structures) with hardware and software to assess the weld quality of fillet, overlap, and butt welds. This system shows acceptable variations in continuous scanning of weld toe radii of $0.5 \mathrm{~mm}$ and a slightly larger variation at weld toe radii of around $1 \mathrm{~mm}$. The system is also capable of continuous measurement of the weld throat thickness with a small variation of $3.5 \%$ and weld undercuts with a variation of $17 \%$.

Ushakov and Davydov [9] conducted a review of ISO and EN standards for the ultrasonic testing of welded joints, particularly with respect to the EN 1712, EN 1713, and EN 1714 European standards in comparison with the Russian GOST (State Standard) 14782. They concluded that no substantial differences between these documents could be found.

Lubecki and Bai [10] developed a weld monitoring system for manual or robotic TIG/MIG (Tungsten inert gas/Metal inert gas) welding to allow the detection of process inconsistency and to access the welding quality in real time. This method is based on signal analysis in the time and frequency domains, enabling feedback to the robot controller in real time. The results showed that the approach was able to monitor the welding processes and correlate it with the given weld defects.

Toivanen et al. [11] examined the manufacturing and conformity of welded products and the significance of co-operation of different functions to welding quality. Their study focused on costs arising from nonconformity from a manufacturing perspective. They discussed unnecessary costs, claim costs and warranty costs in the production chain. These authors furthermore provided an overview of the challenges in welding manufacturing in the engineering field based on empirical research in the industry, and showed that failures and defects are identifiable and known in companies, but are very rarely the root cause of imperfections. Manufacturing requirements go habitually unrecognized at the many levels of organization. One of the main obstacles to improving welding 
functions is the lack of cooperation and knowledge of the demands of welding. This can cause continuous nonconformity in products and in welding manufacturing. Toivanen et al. [11] concluded that coordinating welding functions would provide advantages in terms of the profitability and quality in manufacturing. For example, the ISO 3834 standard ensures welding quality requirements and provides guidelines for good welding production. It emphasizes continuous improvement, control of welding operations, and the importance of a welding coordinator. By employing standards, the tool by which welding operations can be improved for entire productions, the benefits are wider than the mere focus on welding action. It is important that companies themselves are able to respond to the different quality requirements implied by the standards or to use the standards to determine their own quality level and guidelines, clarifying production in order to increase productivity and profitability.

\section{Quality Management in Welding}

\subsection{Introduction}

ISO 9001 [12] contains certification rules for companies that, in brief, aim to produce a particular product (or provide a service) at a level of quality that can be trusted to meet the customer's requirements. This quality should be guaranteed and sustained, e.g., the product must be obtained in a controlled manner and meet the desired requirements. Over time, certified companies have adapted and rewritten documents in accordance with the natural evolution of manufactured products, provided services, or manufacturing methods. These documents tell how a particular operation, for example MIG welding, should be performed-check welding manuals; what is to be welded-check the drawings; how the welding area is dealt with in the company-check the welding procedures; how to control whether or not the welding is carried out well-check the control guide.

One of the key points of a responsible welding task is the warranty for correct and reliable work, but in case of failure, it should be possible to determine the causes and repair the consequences in a timely fashion. This issue is referred to as traceability and, in the case of welding, it consists, among other management actions, in having properly qualified and referenced welders, e.g., the welder "Xan" will have a punch with the letter " $X$ " to indelibly mark, like a signature, the welding he has performed. This welding work can, with reference to the quality criterion, be inspected by a supervisor in order to certify the work, who in turn will assess the work quality and (eventually) also mark the character " $\mathrm{Q}$ " on the structure or component. Of course, a written or recorded report should indicate any nonconformities, working as a continuous incentive in the company's pursuit of quality improvement.

Reference ISO 14731 (2019) [13] indicates the following elements for identification and traceability:

- Identification of production plans (procedures, processes, drawings, etc.);

- Identification of the route card (registration of processes and inspections made to a determined component);

- Identification of the location of welds in the construction;

- Identification of procedures and personnel for non-destructive testing;

- Identification of consumables (e.g., name, reference, manufacturer);

- Identification and/or traceability of base material (e.g., type, lot number);

- Identification of repaired areas in the part;

- Identification of local to fit temporary parts (e.g., temporary attachment - these parts serve for example, as temporary lugs to move the component under construction and are removed by the conclusion of the work);

- Traceability that allows knowing each particular bead made by a specific automated welding system;

- Traceability to associate the welder or welding operator to each specific bead;

- Traceability between the welding procedure and the welding done. 
Naturally, these precautions and the associated documentation have as their main objective the certification of process control. Despite the highest professionalism being invested in welding work, trouble may occur, thus leading to serious problems with respect to product safety and durability.

Welded construction requires, throughout practically the entire world, the strict fulfilment of all welding standards, both at the personnel level (operator, supervisor, engineer, etc.), and with respect to welding procedures and the associated equipment and processes, among other items.

\subsection{CE Marking}

The CE marking for a particular product indicates its compliance with harmonized legislation (this means that all European standards must follow the national standardization organizations). In practice, given the EU "New Approach" legislation, this promotes the free circulation of the product within the European Economic Area. The CE marking is a harmonization and unification tool for procedures, standards and legislation, meeting the European internal market and uniform conditions for the marketing of safe products in the EU (Decision No 768/2008/EC—conformity).

Actually, in the EU, alongside the usual procedure for machines (Directive 2006/42/EC), toys (Directive 2009/48/EC), pressurized equipment (Directive 2014/68/EU), etc., the application of EU Regulation 305/2011 is also mandatory for metal structures (e.g., factory or residential buildings, etc.). Certification on the basis of the EN 1090 standards-Execution of steel structures and aluminium structures-replaces the certification process on the basis of DIN 18800-7 [14]—steel structures—and DIN V 4113-3 [15]—aluminium structures. Norm EN 1090 specifies that all products manufactured for permanent incorporation into construction and civil works for trade in the European Union market must be CE marked. Thus, EN 1090 certification enables manufacturing companies to CE mark steel and aluminium components and structures. The main change with the application of this standard is the obligation on companies to define and follow procedures for conformity assessment of their products.

\subsubsection{EN 1090}

The EN 1090 standard, in its latest version, consists of 5 sections:

- EN 1090-1 [16]-Requirements for conformity assessment of structural components.

- EN 1090-2 [17]-Technical requirements for steel structures.

- EN 1090-3 [18]-Technical requirements for aluminium structures.

- EN 1090-4 [19]-Technical requirements for cold-formed structural steel elements and cold-formed structures for roof (and external roof), ceiling, and for applications in external roof construction, ceiling, floor and walls.

- EN 1090-5 [20]-Technical requirements for cold-formed structural aluminium elements and cold-formed structures for roof (roof), ceiling, floor and wall applications.

The applicability of EN 1090 is dependent on the degree of requirement (responsibility) of the work. In parts 2 and 3 of the standard, 4 execution classes (EXC1 to EXC4) are defined, with an increasing degree of accuracy and rigor from EXC1 to EXC4. For steel structures, until 2018, the indications for selecting the execution class for a given work were given in Annex B-Guidance for determining the execution classes of this standard. As of 2019, this annex was deleted, and part 2 of EN 1090 clearly gives the designer the responsibility of selecting the execution class, now in accordance with Annex $C$ of Eurocode 3-1-1 [21]. In this new version, the default application of EXC2 is also withdrawn in cases where the class is not specified.

It is interesting to note that part 3 of EN 1090-concerning aluminium-already indicated (and continues to refer to) the respective Eurocode (see Eurocode 9-1-1 [22] in the updated version) as a source for the selection of EXCs. From 2019 onwards, the selection of classes will always be based on Eurocode.

Returning to steel structures and Eurocode 3-1-1, to define which EXC to apply to a given structure, it is necessary to know: 
- The intended reliability;

- The type of structure, component or particular detail; and

- The type of loading.

For the management of reliability, the selection of the execution class should be based either on the consequence class (CC) or the reliability class (RC) or both. Once these classes are known, the project designer should refer to Table 1 for case or class selection.

Table 1. Execution classes according to EN 1090-2 [17] and Eurocode 3-1-1 [21]. Reproduced from [21], with permission from CEN-CENELEC, published by Portuguese Institute for Quality, 2017.

\begin{tabular}{|c|c|c|}
\hline \multirow{2}{*}{$\begin{array}{c}\text { Class of Consequence (CC) or } \\
\text { Class of Reliability (RC) }\end{array}$} & \multicolumn{2}{|c|}{ Type of Loading } \\
\hline & $\begin{array}{l}\text { Static, Quasi-Static or } \\
\text { Seismic DCL }\end{array}$ & 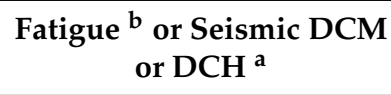 \\
\hline $\mathrm{RC} 3$ or $\mathrm{CC} 3$ & EXC3 ${ }^{c}$ & EXC3 ${ }^{c}$ \\
\hline $\mathrm{RC} 2$ or $\mathrm{CC} 2$ & EXC2 & EXC3 \\
\hline $\mathrm{RC} 1$ or $\mathrm{CC} 1$ & EXC1 & EXC2 \\
\hline \multicolumn{3}{|l|}{ List of symbols: } \\
\hline \multicolumn{3}{|c|}{$\begin{array}{l}\text { a-Class of seismic ductility defined in EN 1998-1: Low = DCL; Mid = DCM; High = DCH } \\
\text { b-Fatigue; see EN 1993-1-9 }\end{array}$} \\
\hline
\end{tabular}

It is noted that each country may define, for its own National Annex, whether to use the consequence class, the reliability class, or both, and it may even specify in which situations Table 1 is to be applied.

Eurocode 3-1-1 prescribes that in the concrete case of projects in accordance with Eurocode 3-4-1 [23] (silos) and Eurocode 3-4-2 [24] (tanks, reservoirs), they will be dependent on the consequence class, while those related to Eurocode 3-3-1 [25] (towers and masts) and Eurocode 3-3-2 [26] (chimneys) employ the reliability class.

The class of consequences is related to the number of people at risk, the location of the structure and its height, the type of loads applied, and the economic or environmental cost, among other things. The higher the class, the higher the level of consequence (and risk). For example, a hospital has a higher class than a housing condominium. Table 2 presents the definition of consequence classes according to Eurocode [27].

Table 2. Consequence classes by Eurocode. Reproduced from [27], with permission from CEN-CENELEC, published by Portuguese Institute for Quality, 2019.

\begin{tabular}{cll}
\hline Consequence Class & \multicolumn{1}{c}{ Description } & \multicolumn{1}{c}{$\begin{array}{c}\text { Example of Buildings and Civil } \\
\text { Engineering Works }\end{array}$} \\
\hline CC3 & $\begin{array}{l}\text { Hazardous impact consequences } \\
\text { in terms of human lives, damage } \\
\text { on economy, society and/or } \\
\text { environment. }\end{array}$ & $\begin{array}{l}\text { Large stadium stands, public buildings } \\
\text { where the consequences of collapse are } \\
\text { highly hazardous (for example, live } \\
\text { concerts/music performances). }\end{array}$ \\
\hline CC2 & $\begin{array}{l}\text { Medium impact consequences for } \\
\text { human lives, damage on economy, } \\
\text { society and/or environment. }\end{array}$ & $\begin{array}{l}\text { Habitation or office buildings, public } \\
\text { buildings where consequence of collapse } \\
\text { are medium. }\end{array}$ \\
\hline CC1 & $\begin{array}{l}\text { Low or impact consequences for } \\
\text { human lives, damage on economy, } \\
\text { society and/or environment; effects } \\
\text { can be neglected. }\end{array}$ & $\begin{array}{l}\text { Cogriculture activity, with non-permanent } \\
\text { human presence (example: greenhouses, } \\
\text { warehouses, sheds for harvesting } \\
\text { machines). }\end{array}$ \\
\hline
\end{tabular}


Usually, the consequence classes CC1, CC2 and CC3 are associated with the reliability classes RC1, RC2 and RC3. Reliability class refers to the probability of building failure within a certain expectation of lifetime. Reliability indices (ultimate limit states) are thus determined, which will be used in the calculation of structures (Table 3-Eurocode [27]). The reliability class can also be a direct indication of the standard; this is the case for chimney calculation (Table 4).

Table 3. Minimum recommended values for the reliability index (ultimate limit state) according to Eurocode. Reproduced from [27], with permission from CEN-CENELEC, published by Portuguese Institute for Quality, 2019.

\begin{tabular}{ccc}
\hline \multirow{2}{*}{ Reliability Class } & \multicolumn{2}{c}{ Reliability Index } \\
\cline { 2 - 3 } & Reference Period of 1 year & Reference Period of 50 years \\
\hline RC3 & 5,2 & 4,3 \\
\hline RC2 & 4,7 & 3,8 \\
\hline RC1 & 4,2 & 3,3 \\
\hline
\end{tabular}

Table 4. Reliability classes for the calculation of chimneys according to [26]. Reproduced from [26], with permission from CEN-CENELEC, published by Portuguese Institute for Quality, 2006.

\begin{tabular}{cl}
\hline Reliability Class & \multicolumn{1}{c}{ Case } \\
\hline RC3 & $\begin{array}{l}\text { Chimneys for special sites, such as nuclear } \\
\text { powerplants or densely inhabited urban places. } \\
\text { Main chimneys of industrial powerplants, with a high } \\
\text { rate of consequences on people or the social } \\
\text { community, in the case of collapse. }\end{array}$ \\
\hline RC2 & $\begin{array}{l}\text { All classified chimneys except for those belonging to } \\
\text { Class 1 or 3. }\end{array}$ \\
\hline RC1 & $\begin{array}{l}\text { Chimneys built in open spaces, where in the case of } \\
\text { collapse, the consequences would be marginal, not } \\
\text { wounding people. Chimneys with less than 16 m } \\
\text { height in non-inhabited zones }\end{array}$ \\
\hline
\end{tabular}

For a company to obtain the certificate of compliance for a given execution class, the following requirements must be met (EN 1090-1 [16]):

- $\quad$ Produce samples for initial type testing (ITT) at the beginning of manufacturing of a new product; in the application of a new manufacturing process, or when the EXC is to be increased, tests or procedures are performed that demonstrate the characteristics of representative products;

- Implement a factory production control (FPC) system; the company must have written procedures, and inspect and test the product/process; and

- Coordinate welding operations-this item is only required for EXC2, EXC3 and EXC4 (Table A.3 of EN 1090-2 [17]).

\subsubsection{ISO 3834 and ISO 14731}

To obtain FPC, it is essential to ensure quality in welding operations according to ISO 3834 [28-33]. This standard defines 3 levels of quality requirements: Comprehensive; Standard; Elementary.

Please note that the first two levels (Comprehensive and Standard) of ISO 3834 require "appropriate welding coordination personnel". A competent welding supervisor (areas of design, manufacture and testing of welded components), as an internationally recognized welding engineer referred to in ISO 14731 (2006) [34] certified by the IIW/EWF (International Institute of Welding/European Welding Federation), will be excellent. However, ISO 3834-Part 6 [33] states that IIW training should be automatically approved, while Annex A of ISO 14731 (2006) does not preclude the manufacturer 
implementing any other qualification for welding coordinators. A qualification awarded, for example, by AWS could surely be recognized as valid-see references AWS B5 [35-37].

At an international level, the welding qualification and certification system is ruled by the International Institute of Welding (IIW), which governs the International Authorization Board (IAB) and accredits entities from various countries; these are known as ANBs (authorized nominated bodies). In Europe, there is an entity, the European Welding Federation (EWF, with similar purposes to IIW), where the IIW and EWF act in concert. As a rule, each country has only one entity ANB approved for "welding education, training and qualification activities", thus apparently having an exclusivity with respect to meeting the requirements of the standard, concerning welding coordination (ISO 14731, 2006). Thus, only this ANB entity is able to award EWF/IIW qualification for IWE-Engineer, IWT-Technologist, and IWS-Specialist levels. Welding in Europe follows international ISO (International Organization for Standardization) European (EN) and American (essentially AWS and ASME) standards. ISO, in the field of welding, collaborates with IIW.

One differentiating aspect of ISO 3834 is that it emphasizes the human factor in welding. In fact, by using ISO 14731 (2006) as a reference, the main tasks requiring correct decisions to be made can be identified based on the qualifications of the worker carrying out the procedure.

ISO 3834 is not a quality system standard created to replace ISO 9001; rather, it is a useful additional tool to be used concurrently. However, ISO 3834 applies independently of ISO 9001. Compliance with requirements in accordance with ISO 3834 requires highly competent welding professionals, where simple company certification by ISO 9001 (also habilitated for welds), does not certify it according to ISO 3834. Therefore, ISO 3834 does not require any external assessment or certification by itself.

Norm ISO 14731 (2006) states that: "Welding is a specific process requiring the coordination of welding operations to achieve confidence in welding fabrication and reliable service performance. Tasks and responsibilities in welding or related activities (e.g., planning, execution, supervision and inspection) should be clearly defined". Annex A of this standard sets out IIW's recommendations (on a voluntary basis) for minimum education, examination and qualification of personnel required for welding coordination:

- International Welding Engineer (IWE), Doc. IAB-002-2000/EWF-409;

- International Welding Technologist (IWT), Doc. IAB-003-2000/EWF-410;

- International Welding Specialist (IWS), Doc. IAB-004-2000/EWF-411.

One aspect that lacks transparency in these IIW recommendations, and also in the ISO 14731 (2006) standard, is a widely criticized restriction with respect to the teaching of welding in universities, whereby these institutions are able to provide technical training only, and for a period not exceeding 93 hours. Currently, in Portugal, there is only one postgraduate course on welding engineering, which is taught by ISQ and comprises 498 hours of lessons. For some companies, only a single welding coordinator may be enough to cover all of the required tasks. For more complex manufacturing, a training team may be required. In addition, it must be mentioned that ISO 14731 (2006) allows the subcontracting of welding supervisors, although the responsibility for the fulfilment of the norm lies with the constructor.

An additional detail of ISO 14731 (2006) is the obvious connection to IIW, which was removed from the new ISO 14731 (2019), which was issued for anti-competitive reasons. Thus, this update represents the end of the reference to IIW and introduces the requirements of welding supervision staff in the revised Annex A. In this way, the clause dictating exclusivity of training via ANBs was removed, allowing universities, for example, to carry out this task.

The required competencies of welding coordination personnel, as set out in the new ISO 14731 (2019), are essentially as follows:

- To have experience in welding similar products in observation of the standards usually followed by the company; 
- To have experience in using company procedures, e.g., WPQR -Welding Procedure Qualification Record and WPS-Welding Procedure Specification;

- To understand ISO 3834 and ISO 14731 (ISO also indicates what expertise is required for welding coordinators);

- To have experience in solving welding problems; and

- To have theoretical knowledge of the framework and/or level of responsibility of the work.

For the latter requirement, the standard specifies three levels of technical competence for welding coordination personnel, where the main contents are as follows:

- Comprehensive: Welding coordination personnel must be highly specialized in the field, including the ability to carry out critical and original evaluations in order to define and develop the best solutions, both technically and economically, under unpredictable and highly complex conditions;

- Specific: Welding coordination personnel should have advanced knowledge in the field, including the ability to critically evaluate the best solutions, both technically and economically, under unpredictable and complex conditions; and

- Basic: Welding coordination personnel should have fundamental knowledge in the area, including the ability to identify and develop appropriate solutions to current welding issues.

In this standard, "welding coordinator" is a job (or position) held by a company worker, which means the manufacturer is required to establish whether a particular person has the knowledge, skills and experience to fulfil the job requirements; the competence obtained via a welding course is not enough. In fact, the standard states that the "welding coordinator" should be an expert with respect to the materials, construction details, and welding processes practiced in the company.

It is important to note that with this new approach, in terms of qualification of welding coordinating personnel, ISO 14731 (2019) [13] has become very similar to US standards AWS B5 [35-37], clearly requiring experience in a factory environment in addition to theoretical qualifications.

\subsection{Qualification of Welders and Operators}

A good weld is the one where there energy is saved, it has a smooth and uniform surface, it is good looking, and is resistant to the mechanical actions for which it was designed. In practical terms, it is desirable that a weld be executed in an efficient way, reflecting the welder's expertise in the task. Naturally, to obtain a good weld, the correct ingredients must be involved in the task:

- The adequate welding machine;

- An expert and professional welder, with knowledge in adjusting the welding machine, also operating with skill and care;

- The correct and properly controlled welding material and the respective electrode coating,

The guarantee of quality implied by these conditions only holds with efficient control before and after any welding operation.

The qualification of welders and operators of automatic welding machines is mandatory for companies aiming to meet the requirements of the above standards. The most typical exams in Europe follow ISO 9606 in its five parts [38-42] for welders and ISO 14732 [43] for operators. However, it is also possible to find entities that certify welders using other standards, such as the American ASME IX and API 1104.

Despite rare exceptions, the general rules in the standard specify that each examination qualifies a welder for only one process, materials area, welding position, or geometry of elements to weld.

The ISO 9606-1 [38] qualification field and variables in fusion welding of steels are:

- Welding process (according to ISO 25901-3 [44])

- $\quad$ Type of part to weld (plate or pipe) 
- Welding joint (butt or fillet)

- Group of filler material

- $\quad$ Type of filler material

- Dimensions of the part to weld (tube thickness and outside diameter)

- Welding Position

- Welding details (gas by root side, one-side welding; single pass, etc.)

- Base material group (obviously, if we are in ISO 9606-1 [38], then it refers to steel, but it is necessary to mention which type is it according to ISO/TR 15608 [45]).

Dimensions of the parts to be welded in the examination are shown in Figures 1-4.

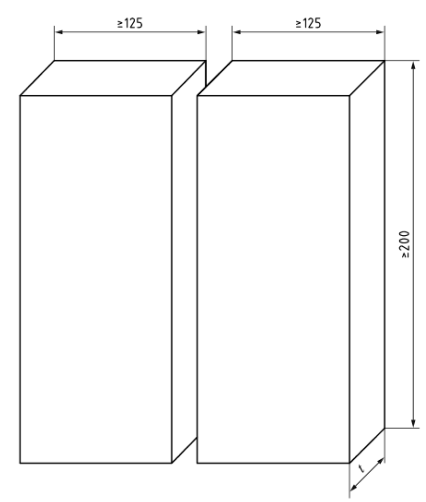

Figure 1. Dimensions of plates for welding expertise exam on butt welding. Reproduced from [38], with permission from CEN-CENELEC, published by Portuguese Institute for Quality, 2017.

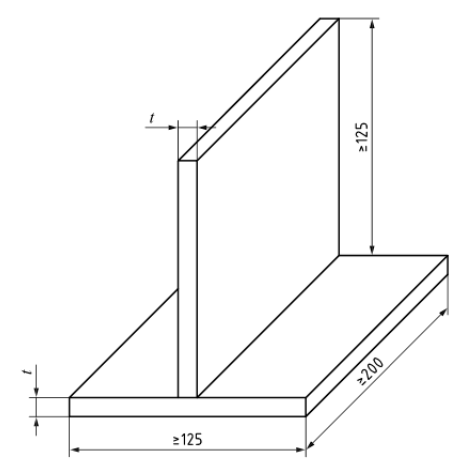

Figure 2. Dimensions of plates for welding expertise exam on fillet welded joints. Reproduced from [38], with permission from CEN-CENELEC, published by Portuguese Institute for Quality, 2017.

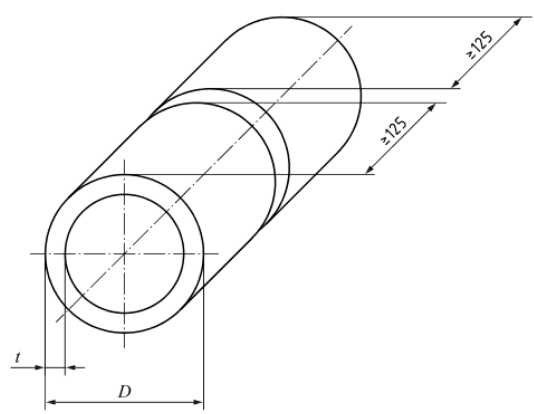

Figure 3. Dimensions of pipes for welding expertise exam on butt welded joints. Reproduced from [38], with permission from CEN-CENELEC, published by Portuguese Institute for Quality, 2017. 


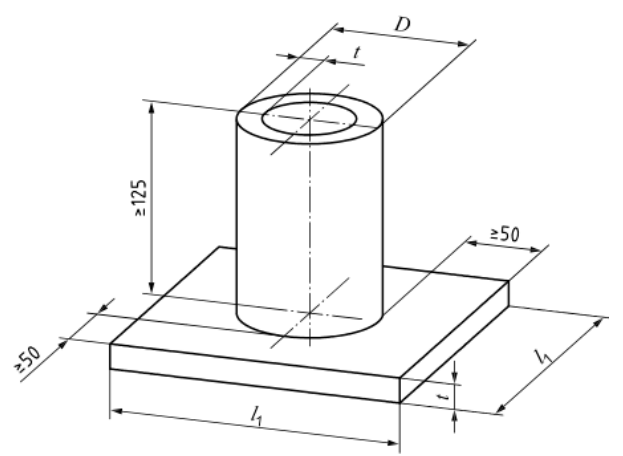

Figure 4. Dimensions of pipes and plates for welding expertise exam on pipe-to-plate fillet welded joints. Reproduced from [38], with permission from CEN-CENELEC, published by Portuguese Institute for Quality, 2017.

Once the demonstration of welding expertise has been concluded, the Examiner checks visually whether the welding looks correct, has a smooth surface and the correct dimensions. If so, the technological tests listed in Table 5 are performed, with test specimens being cut from the formerly welded elements.

Table 5. Tests to be performed on the welded joints included in the exam on welding ability. Reproduced from [38], with permission from CEN-CENELEC, published by Portuguese Institute for Quality, 2017.

\begin{tabular}{|c|c|c|}
\hline Method of Test & Butt-Welded Joints & Fillet-Welded Joints \\
\hline $\begin{array}{l}\text { Visual inspection according to } \\
\text { ISO17637 }\end{array}$ & Mandatory & Mandatory \\
\hline $\begin{array}{l}\text { X-Ray inspection according to } \\
\text { ISO } 17636\end{array}$ & Mandatory ${ }^{a, b}, \mathrm{c}$ & Optional \\
\hline $\begin{array}{l}\text { 3-Point bending test according to } \\
\text { ISO } 5173\end{array}$ & Mandatory ${ }^{a, b, d}$ & Not applicable \\
\hline Fracture test according to ISO 9017 & Mandatory ${ }^{a, b, d}$ & Mandatory e,f \\
\hline \multicolumn{3}{|l|}{ List of symbols: } \\
\hline \multicolumn{3}{|c|}{$\begin{array}{l}\text { a-Usable with any of following tests: X-ray, bending or fracture. } \\
\text { b-X-ray application in processes 131, } 135,138 \text { and } 311 \text {; impose bending and fracture tests to the part in the exam. } \\
\text { c-X-ray can be substituted by ultrasonic examination according to ISO } 17640 \text {, provided the thickness of the parts in } \\
\text { the test is equal or exceeds } 8 \mathrm{~mm} \text {. Valid only for ferritic steels. Tests mentioned in " } b \text { " are not mandatory. } \\
\text { d-For pipes with external diameter smaller than (or at least equal to) } 25 \mathrm{~mm} \text {, bending or fracture tests may be } \\
\text { substituted by tensile tests of a test specimen with holes (consult ISO } 9017 \text { ). } \\
\text { e-Fracture tests can be substituted by a macroscopic examination according to ISO 17639, in at least two sections, } \\
\text { with it being mandatory that one of them should be extracted from the extreme points of the weld. } \\
\text { f-Fracture test in pines can be substituted by X-rav examination. }\end{array}$} \\
\hline
\end{tabular}

The standard also details the dimensions of the samples to be extracted from welded specimens, among other details-see [38].

After the first exam, the welder requires a renewed professional certificate every 6 months; however, it may be converted into "lifetime" certification, depending on the welder having always worked in the same area of activity for which they have been qualified and for which they have submitted the revalidation options (see, for example, [38]). The 6-month validity confirmation for continuous activity can be carried out by the bureau of quality assessment, or responsibility for this can be taken by the welding quality staff of the company itself, if they are accredited for this objective. The welder must be active in the same initial specialty of their qualification. 


\subsection{Qualification of a Welding Procedure}

According to ISO 15607 [46], a welding procedure is a "course" or specific path of actions to follow in order to perform welding, which indicates the welding process (s), base materials, consumables, preparation, preheating (if necessary), the welding method and control, after-heat treatment (if necessary), and the equipment to be used for welding.

To obtain qualification, a welding procedure should follow The Preliminary Welding Procedure Specification (PWPS), a document describing the variables required for the welding procedure. Next, tests should be performed and the results recorded in accordance with the qualification method being used (see Table 6).

Table 6. Methods for qualification according to ISO 15607. Reproduced from [46], with permission from CEN-CENELEC, published by Portuguese Institute for Quality, 2008.

\begin{tabular}{cl}
\hline \multicolumn{1}{c}{ Method Based on } & \multicolumn{1}{c}{ Application } \\
\hline Test of the welding procedure & $\begin{array}{l}\text { Always applicable, with the exception of when the procedure } \\
\text { test is not adequate to the joint geometry, fixture conditions, or } \\
\text { local joint accessibility }\end{array}$ \\
\hline \multirow{3}{*}{ Test of the welding consumables } & $\begin{array}{l}\text { Application restricted to welding processes using consumables. } \\
\text { Testing of consumables must include material to weld for } \\
\text { production. ISO 15610 presents more limitations about } \\
\text { material and other parameters }\end{array}$ \\
\hline Previous welding practice & $\begin{array}{l}\text { Has a limited application to welding procedures formerly used } \\
\text { in a large number of welding of components and joints with } \\
\text { similar materials. Specifications can be found in ISO 15611. }\end{array}$ \\
\hline Standard welding procedure & $\begin{array}{l}\text { Similar to the first case (testing the welding procedure). } \\
\text { Specifications are in ISO 15612 }\end{array}$ \\
\hline & $\begin{array}{l}\text { In principle, it may always be applied, but requires the } \\
\text { fabrication of a part for testing under similar (normal) } \\
\text { conditions of production. It is adequate for large production. } \\
\text { Specifications can be found in ISO 15613. }\end{array}$ \\
\hline
\end{tabular}

This register is called the Welding Procedure Qualification Record (WPQR), and it contains all the variables indicated by the case-specific standard. Finally, the Welding Procedure Specification (WPS) is written in accordance with the method used (Table 6). The various parts of ISO 15609 [47-52], as well as ISO 14555 [53], ISO 15620 [54] and ISO 17660 [55,56], define the WPS format and other requirements for various welding processes (e.g., part 1 of ISO 15609 is for the electric arc [47]).

If, for instance, it is necessary for the welder to be qualified by means of a welding procedure test (as in the 1st case in Table 6), then the specific standard in the welding process of the work must be followed, namely, one of each of the 13 parts of ISO 15614 [57-70] in active status, with the $1^{\text {st }}$, ISO 15614 [57], being dedicated to arc welding for steels, nickel and nickel alloys (Part 9 of the previously mentioned standard has been deactivated; see references). Their up-to-date versions are listed in references [57-70]

In Europe, welded construction is performed under ISO, EN and Eurocode Standards, but alternatively, Codes and Standards from the USA also apply. For example, in steel construction, the AWS D1.1 Standard [71] is one of the most widely used, but as an alternative, and also from USA, the ASME-American Society of Mechanical Engineers Codes-can also be followed, among others.

\section{Welding Defects, Levels of Acceptance, and Inspection}

The quality level of a weld depends on several factors, such as the weld material itself, the welding conditions, and the operator's experience (this one, perhaps, is the most critical). 
Please note that, even in automated processes, failure may occur, such as, for example, the joint's lack of preset tolerance. Therefore, it is predictable that such a joint will never be perfect, thus warranting the rigorous continuity of the weld materials.

The ISO 6520 standards [72,73] describe hypothetical defects that may occur in welded joints, particularly in processes involving fusion and pressure load. They define that:

- A weld imperfection is a lack of continuity or a deviation of the defined geometry;

- A weld defect is an inadmissible imperfection.

Part 1 of the ISO 6520 standard [72] lists the following types of defects:

$1-$ Cracks

2-Cavities (or porosities)

3-Solid inclusions

4-Lack of weld fusion and penetration

5 - Shape or dimensional defects

6-Various defects

The ISO 5817 standard [74] provides a scale for the acceptance levels of defects based on a list of criteria in welding through the fusion of steel, nickel, titanium and alloys (exception for laser e-beam welding). For aluminium and alloys, the standards to apply are included in ISO 10042 [75].

Levels of acceptance for the quality of laser and beam welding are included in ISO 13919_Part 1 [76] and ISO 13919_-Part 2 [77] with respect to steel, nickel, titanium and alloys, and aluminium and weldable alloys, respectively.

ISO 5817 [74] sets the rules for acceptance/rejection of weld defects based on 3-level criteria, named B, C and D. Level B is the most exigent, while the quality rate is lower in C, with D being the one in which the largest number of defects is accepted.

The control of welded constructions - in the sense of inspection and testing-should be performed prior, during, and after welding operations.

In a general sense, prior to carrying out welding work, the following items are to be checked: Materials (base and weld), including the preparation of the joint; welding machines and accessories (for example, eventual use of welding rigs); conditions of work (indoors/outdoors of factory areas); personnel (from the welder up to the welding work supervisor); and orders and methods of fabrication (drawings, specifications, welding procedures, etc.), according to ISO 14731, 2019 standard.

During welding operations, the complete fulfillment of welding specifications (and process parameters) should be ensured, as well as the checking of preheating control, temperature, cleaning between each welding pass (if applicable) and the correct use/handling of consumable materials (for example, the use of a quiver for preheating of coated electrodes).

Sometimes, it is important to order intermediate examinations as part of the welding process, checking for the accuracy of dimensions, either of the welds or of unavoidable geometric distortions.

After the conclusion of the welding construction, it is sometimes necessary to assess welds, and even the whole construction, with respect to the project specifications (paying attention to excessive residual strains, for example). Naturally, this control could be more or less rigorous and deep, depending on several parameters, namely, the safety and requirements imposed on the client by the contract. Therefore, before selecting the method of control, the following points should be considered:

- $\quad$ The welding process used;

- The weld metal and thermal treatment if requested;

- Dimensions, shape and dimensional tolerances of the welded work;

- $\quad$ Type of joint and geometry;

- $\quad$ Shape of component (with respect to its accessibility, surface type, etc.);

- Quality level imposed (for example, by ISO 5817 [74]); 
- Provision of type and orientation of imperfections;

- Results and reports of eventual post-welding work (for example, thermal treatments or suppression of warp distortions).

After the welding process, two types of control can be used: destructive and the non-destructive.

Destructive control is naturally expensive, as some portion of the part to be examined is removed, thus rendering the component (or part of it) unusable. This option is reasonable only in critical cases (for example, with damage reported during working time) or involving large series of fabrication, being wise to perform that type of test.

Normally, destructive tests consist of compression, tension, fatigue, and hydrostatic pressure, among other things. Such tests should achieve the breakdown of the test specimen. This test shows, for example, if rupture occurs at the weld (this includes the thermally affected zone) or the base material.

Non-destructive procedures are known by the English Acronyms NDT-Non-Destructive Testing, and NDE-Non-Destructive Examination. Examples include visual inspection, searching for dimensional errors, pressure tightness, penetrating liquids (for crack detection), magnetic particles, Eddy currents, X-ray, and ultrasonic inspection.

\section{Conclusions}

Welding is a way joining, in a continuous mode, a variety of materials. The emphasis is placed on responsibility in welding works, whereby welding processes must be always carried out by qualified operators and supervised by a certified inspections team. The fulfillment of the numerous standards, either related to welding processes, or operator procedures, equipment, among other things, is mandatory.

Standardization of welding processes and procedures exists primarily for safety reasons. In fact, the failure of an in-service welding can lead to catastrophic events; therefore, quality assessment in welding is of outmost importance.

Quality management in welding involves two main aspects: (i) the management of processes, procedures and personnel; and (ii) welding quality control. Naturally, both are indispensable for proper quality assurance.

Manufacturers of welded construction products usually implement the ISO 9001 quality assurance system; however, in Europe, the free movement of products and the obligation to obtain a CE marking makes it necessary to certify the product as well, and not just the company. Therefore, certification on the basis of EN 1090 is mandatory. In turn, this standard requires companies to have a factory production control system, which is achieved by complying with ISO 3834-which determines the quality requirements for fusion welding of metallic materials-and ISO 14731—which is related to the coordination of welding operations. The objective is to achieve confidence in welding fabrication and reliable service performance. Therefore, the qualification of welding-related personnel in the company, from welders and welding machine operators to the welding coordinator, is essential.

As a rule, each welding process requires a specific certification for both the operator and the welding procedure.

Despite the numerous precautions taken in welding operations, there are inevitable defects-at the very least as a result of the unavoidable effect of heat-affected zones-that need to be quantified and qualified-for example, through the use of non-destructive examination-as well as to have their acceptance levels defined-for example, by using ISO 5817. The results will dictate the acceptance or rejection of the examined component in welded construction.

Author Contributions: Conceptualization, A.B.P.; Funding acquisition, A.B.P.; Investigation, A.B.P.; Writing—original draft, A.B.P.; Writing—review \& editing, F.J.M.Q.d.M., A.B.P. All authors have read and agreed to the published version of the manuscript.

Funding: This work was supported by the projects UID/EMS/00481/2019-FCT_FCT_Fundação para a Ciencia e a Tecnologia; CENTRO-01-0145-FEDER-022083-Centro Portugal Regional Operational Programme (Centro2020), under the PORTUGAL 2020 Partnership Agreement, through the European Regional Development Fund. 
Acknowledgments: The authors wish to thank Portuguese Institute for Quality for the authorization copyright of the standards. These standards can be consulted in its entirety through the Portuguese Institute for Quality.

Conflicts of Interest: The authors declare no conflict of interest.

\section{References}

1. ISO/TR. 25901-1: 2016-Welding and Allied Processes_Vocabulary-Part 1: General Terms; International Organization for Standardization: Geneva, Switzerland, 2016.

2. ISO. 4063:2009—Welding and Allied Processes-Nomenclature of Processes and Reference Numbers; International Organization for Standardization: Geneva, Switzerland, 2009.

3. AWS. A3.0M/A3.0:2010—Standard Welding Terms and Definitions-Including Terms for Adhesive Bonding, Brazing, Soldering, Thermal Cutting, and Thermal Spraying; American Welding Society: Miami, FL, USA, 2010.

4. Stavridis, J.; Papacharalampopoulos, A.; Stavropoulos, P. A cognitive approach for quality assessment in laser welding. Procedia CIRP 2018, 72, 1542-1547. [CrossRef]

5. Summerville, C.; Compston, P.; Doolan, M. A comparison of resistance spot weld quality assessment techniques. Procedia Manuf. 2019, 29, 305-312. [CrossRef]

6. Szeleziński, A.; Muc, A.; Murawski, L. Quality Assessment of Welded Joints using the Mean Value Distribution of Amplitude Spectrums Calculated by the Time Window Method. J. KONES 2017, 24, 263-270. [CrossRef]

7. Stavridis, J.; Papacharalampopoulos, A.; Stavropoulos, P. Quality assessment in laser welding: a critical review. Int. J. Adv. Manuf. Technol. 2018, 94, 1825-1847. [CrossRef]

8. Stenberg, T.; Barsoum, Z.; Åstrand, E.; Öberg, A.E.; Schneider, C.; Hedegård, J. Quality control and assurance in fabrication of welded structures subjected to fatigue loading. Weld. World 2017, 61, 1003-1015. [CrossRef]

9. Ushakov, V.M.; Davydov, D.M. A review of international (ISO) and European (EN) standards for the ultrasonic testing of welded joints. Russ. J. Nondestruct. Test. 2013, 49, 61-66. [CrossRef]

10. Lubecki, T.M.; Bai, F. Weld quality assessment based on arc sensing for robotic welding. In Proceedings of the IEEE International Conference on Advanced Intelligent Mechatronics (AIM), Busan, Korea, 7-11 July 2015; pp. 1496-1501. [CrossRef]

11. Toivanen, J.; Kah, P.; Martikainen, J. Quality Requirements and Conformity of Welded Products in the Manufacturing Chain in Welding Network. Int. J. Mech. Eng. Appl. 2015, 3, 109-119. [CrossRef]

12. ISO. 9001:2015-Quality Management Systems_Requirements; International Organization for Standardization: Geneva, Switzerland, 2015.

13. ISO. 14731:2019-Welding Coordination-Tasks and Responsibilities; International Organization for Standardization: Geneva, Switzerland, 2019.

14. DIN. 18800-7:2008—Steel Structures—Part 7: Execution and Constructor's Qualification; German Institute for Standardization: Berlin, Germany, 2008.

15. DIN. V 4113-3:2003 Aluminium Constructions under Predominantly Static Loading-Part 3: Execution and Qualification of Constructors; German Institute for Standardization: Berlin, Germany, 2003.

16. EN. 1090-1: $2009+$ A1:2011-Execution of Steel Structures and Aluminium Structures_Part 1: Requirements for Conformity Assessment of Structural Components; European Committee for Standardization: Brussels, Belgium, 2011.

17. EN. 1090-2:2018-Execution of Steel Structures and Aluminium Structures_Part 2: Technical Requirements for Steel Structures; European Committee for Standardization: Brussels, Belgium, 2018.

18. EN. 1090-3:2008-Execution of Steel Structures and Aluminium Structures_Part 3: Technical Requirements for Aluminium Structures; European Committee for Standardization: Brussels, Belgium, 2008.

19. EN. 1090-4:2018-Execution of Steel Structures and Aluminium Structures. Technical Requirements for Cold-Formed Structural Steel Elements and Cold-Formed Structures for Roof, Ceiling, Floor and Wall Applications; European Committee for Standardization: Brussels, Belgium, 2018.

20. EN. 1090-5:2017-Execution of Steel Structures and Aluminium Structures. Technical Requirements for Cold-Formed Structural Aluminium Elements and Cold-Formed Structures for Roof, Ceiling, Floor and Wall Applications; European Committee for Standardization: Brussels, Belgium, 2018.

21. EN. 1993-1-1:2005/A1:2014—Eurocode 3. Design of Steel Structures—Part 1-1: General Rules and Rules for Buildings; European Committee for Standardization: Brussels, Belgium, 2014. 
22. EN. 1999-1-1:2007/A2:2013-Eurocode 9-Design of Aluminium Structures-Part 1-1: General Structural Rules; European Committee for Standardization: Brussels, Belgium, 2013.

23. EN. 1993-4-1:2007/A1:2009_Eurocode 3. Design of Steel Structures_Part 4-1: Silos; European Committee for Standardization: Brussels, Belgium, 2009.

24. EN. 1993-4-2:2007-Eurocode 3. Design of Steel Structures-Part 4-2 Tanks; European Committee for Standardization: Brussels, Belgium, 2007.

25. EN. 1993-3-1:2006/A1:2009_Eurocode 3. Design of Steel Structures_Part 3-1: Towers, Masts and Chimneys-Towers and Masts; European Committee for Standardization: Brussels, Belgium, 2009.

26. EN. 1993-3-2:2006-Eurocode 3. Design of Steel Structures-Part 3-2: Towers, Masts and Chimneys-Chimneys; European Committee for Standardization: Brussels, Belgium, 2006.

27. EN. 1990:2002/A2:2010-Eurocode-Basis of Structural Design; European Committee for Standardization: Brussels, Belgium, 2010.

28. ISO. 3834-1:2005-Quality Requirements for Fusion Welding of Metallic Materials_Part 1: Criteria for the Selection of the Appropriate Level of Quality Requirements; International Organization for Standardization: Geneva, Switzerland, 2005.

29. ISO. 3834-2:2005-Quality Requirements for Fusion Welding of Metallic Materials_Part 2: Comprehensive Quality Requirements; International Organization for Standardization: Geneva, Switzerland, 2005.

30. ISO. 3834-3:2005-Quality Requirements for Fusion Welding of Metallic Materials_Part 3: Standard Quality Requirements; International Organization for Standardization: Geneva, Switzerland, 2005.

31. ISO. 3834-4:2005-Quality Requirements for Fusion Welding of Metallic Materials_Part 4: Elementary Quality Requirements; International Organization for Standardization: Geneva, Switzerland, 2005.

32. ISO. 3834-5:2015-Quality Requirements for Fusion Welding of Metallic Materials_Part 5: Documents with which it Is Necessary to Conform to Claim Conformity to the Quality Requirements of ISO 3834-2, ISO 3834-3 or ISO 3834-4; International Organization for Standardization: Geneva, Switzerland, 2015.

33. ISO/TR. 3834-6:2007-Quality Requirements for Fusion Welding of Metallic Materials-Part 6: Guidelines on Implementing ISO 3834; International Organization for Standardization: Geneva, Switzerland, 2007.

34. ISO. 14731:2006-Welding Coordination-Tasks and Responsibilities; International Organization for Standardization: Geneva, Switzerland, 2006.

35. AWS. B5.1:2013-AMD1-Specification for the Qualification of Welding Inspectors; American Welding Society: Miami, FL, USA, 2013.

36. AWS. B5.9:2006 — Specification for the Qualification of Welding Supervisors; American Welding Society: Miami, FL, USA, 2010.

37. AWS. B5.16:2006 - Specification for the Qualification of Welding Engineers; American Welding Society: Miami, FL, USA, 2006.

38. ISO. 9606-1:2012—Qualification Testing of Welders_Fusion Welding_Part 1: Steels; International Organization for Standardization: Geneva, Switzerland, 2012.

39. ISO. 9606-2:2004-Qualification Testing of Welders_Fusion Welding_Part 2: Aluminium and Aluminium Alloys; International Organization for Standardization: Geneva, Switzerland, 2004.

40. ISO. 9606-3:1999_Approval Testing of Welders_Fusion Welding_Part 3: Copper and Copper Alloys; International Organization for Standardization: Geneva, Switzerland, 1999.

41. ISO. 9606-4:1999_Approval Testing of Welders_Fusion Welding_Part 4: Nickel and Nickel Alloys; International Organization for Standardization: Geneva, Switzerland, 1999.

42. ISO. 9606-5:2000-Approval Testing of Welders_Fusion Welding-Part 5: Titanium and Titanium Alloys, Zirconium and Zirconium Alloys; International Organization for Standardization: Geneva, Switzerland, 2000.

43. ISO. 14732:2013 - Welding Personnel-Qualification Testing of Welding Operators and Weld Setters for Mechanized and Automatic Welding of Metallic Materials; International Organization for Standardization: Geneva, Switzerland, 2013.

44. ISO/TR. 25901-3:2016—Welding and Allied Processes_Vocabulary_Part 3: Welding Processes; International Organization for Standardization: Geneva, Switzerland, 2016.

45. ISO/TR. 15608:2017-Welding—Guidelines for a Metallic Materials Grouping System; International Organization for Standardization: Geneva, Switzerland, 2017.

46. ISO. 15607:2003—Specification and Qualification of Welding Procedures for Metallic Materials—General Rules; International Organization for Standardization: Geneva, Switzerland, 2003. 
47. ISO. 15609-1:2019—Specification and Qualification of Welding Procedures for Metallic Materials_Welding Procedure Specification-Part 1: Arc Welding; International Organization for Standardization: Geneva, Switzerland, 2019.

48. ISO. 15609-2:2001—Specification and Qualification of Welding Procedures for Metallic Materials_Welding Procedure Specification-Part 2: Gas Welding; International Organization for Standardization: Geneva, Switzerland, 2001.

49. ISO. 15609-3:2004-Specification and Qualification of Welding Procedures for Metallic Materials_Welding Procedure Specification-Part 3: Electron Beam Welding; International Organization for Standardization: Geneva, Switzerland, 2004.

50. ISO. 15609-4:2009—Specification and Qualification of Welding Procedures for Metallic Materials-Welding Procedure Specification - Part 4: Laser Beam Welding; International Organization for Standardization: Geneva, Switzerland, 2009.

51. ISO. 15609-5:2011-Specification and Qualification of Welding Procedures for Metallic Materials-Welding Procedure Specification-Part 5: Resistance Welding; International Organization for Standardization: Geneva, Switzerland, 2011.

52. ISO. 15609-6:2013-Specification and Qualification of Welding Procedures for Metallic Materials_Welding Procedure Specification-Part 6: Laser-Arc Hybrid Welding; International Organization for Standardization: Geneva, Switzerland, 2013.

53. ISO. 14555:2017-Welding-Arc Stud Welding of Metallic Materials; International Organization for Standardization: Geneva, Switzerland, 2017.

54. ISO. 15620:2019-Welding-Friction Welding of Metallic Materials; International Organization for Standardization: Geneva, Switzerland, 2019.

55. ISO. 17660-1:2006-Welding—Welding of Reinforcing Steel_Part 1: Load-Bearing Welded Joints; International Organization for Standardization: Geneva, Switzerland, 2006.

56. ISO. 17660-2:2006-Welding—Welding of Reinforcing Steel_Part 2: Non Load-Bearing Welded Joints; International Organization for Standardization: Geneva, Switzerland, 2016.

57. ISO. 15614-1:2017_Specification and Qualification of Welding Procedures for Metallic Materials_Welding Procedure Test-Part 1: Arc and Gas Welding of Steels and Arc Welding of Nickel and Nickel Alloys; International Organization for Standardization: Geneva, Switzerland, 2017.

58. ISO. 15614-2:2005—Specification and Qualification of Welding Procedures for Metallic Materials_Welding Procedure Test-Part 2: Arc Welding of Aluminium and Its Alloys; International Organization for Standardization: Geneva, Switzerland, 2005.

59. ISO. 15614-3:2008—Specification and Qualification of Welding Procedures for Metallic Materials_Welding Procedure Test-Part 3: Fusion Welding of Non-Alloyed and Low-Alloyed Cast Irons; International Organization for Standardization: Geneva, Switzerland, 2008.

60. ISO. 15614-4:2005—Specification and Qualification of Welding Procedures for Metallic Materials_Welding Procedure Test-Part 4: Finishing Welding of Aluminium Castings; International Organization for Standardization: Geneva, Switzerland, 2005.

61. ISO. 15614-5:2004-Specification and Qualification of Welding Procedures for Metallic Materials_Welding Procedure Test-Part 5: Arc Welding of Titanium, Zirconium and Their Alloys; International Organization for Standardization: Geneva, Switzerland, 2004.

62. ISO. 15614-6:2006 —Specification and Qualification of Welding Procedures for Metallic Materials_Welding Procedure Test-Part 6: Arc and Gas Welding of Copper and Its Alloys; International Organization for Standardization: Geneva, Switzerland, 2006.

63. ISO. 15614-7:2016 —Specification and Qualification of Welding Procedures for Metallic Materials_Welding Procedure Test_Part 7: Overlay Welding; International Organization for Standardization: Geneva, Switzerland, 2016.

64. ISO. 15614-8:2016 —Specification and Qualification of Welding Procedures for Metallic Materials_Welding Procedure Test-Part 8: Welding of Tubes to Tube-Plate Joints; International Organization for Standardization: Geneva, Switzerland, 2016.

65. ISO. 15614-1:2000—Specification and Approval of Welding Procedures for Metallic Materials_Welding Procedure Test-Part 9: Underwater Hyperbaric Wet Welding; International Organization for Standardization: Geneva, Switzerland, 2000; Norma inativa.

66. ISO. 15614-10:2005—Specification and Qualification of Welding Procedures for Metallic Materials-Welding Procedure Test_Part 10: Hyperbaric Dry Welding; International Organization for Standardization: Geneva, Switzerland, 2005. 
67. ISO. 15614-11:2002—Specification and Qualification of Welding Procedures for Metallic Materials-Welding Procedure Test-Part 11: Electron and Laser Beam Welding; International Organization for Standardization: Geneva, Switzerland, 2002.

68. ISO. 15614-12:2014-Specification and Qualification of Welding Procedures for Metallic Materials-Welding Procedure Test-Part 12: Spot, Seam and Projection Welding; International Organization for Standardization: Geneva, Switzerland, 2014.

69. ISO. 15614-13:2012—Specification and Qualification of Welding Procedures for Metallic Materials_Welding Procedure Test-Part 13: Upset (Resistance Butt) and Flash Welding; International Organization for Standardization: Geneva, Switzerland, 2012.

70. ISO. 15614-14:2013-Specification and Qualification of Welding Procedures for Metallic Materials-Welding Procedure Test-Part 14: Laser-Arc Hybrid Welding of Steels, Nickel and Nickel Alloys; International Organization for Standardization: Geneva, Switzerland, 2013.

71. AWS. D1.1/D1.1M:2015—Structural Welding Code—Steel; American Welding Society: Miami, FL, USA, 2015.

72. ISO. 6520-1:2007-Welding and Allied Processes-Classification of Geometric Imperfections in Metallic Materials_Part 1: Fusion Welding; International Organization for Standardization: Geneva, Switzerland, 2007.

73. ISO. 6520-2:2013-Welding and Allied Processes-Classification of Geometric Imperfections in Metallic Materials-Part 2: Welding with Pressure; International Organization for Standardization: Geneva, Switzerland, 2013.

74. ISO. 5817:2014-Welding-Fusion-Welded Joints in Steel, Nickel, Titanium and Their Alloys (Beam Welding Excluded)—Quality Levels for Imperfections; International Organization for Standardization: Geneva, Switzerland, 2014.

75. ISO. 10042:2018 -Welding-Arc-Welded Joints in Aluminium and Its Alloys-Quality Levels for Imperfections; International Organization for Standardization: Geneva, Switzerland, 2018.

76. ISO/FDIS. 13919-1_Electron and Laser-Beam Welded Joints-Requirements and Recommendations on Quality Levels for Imperfections_Part 1: Steel, Nickel, Titanium and Their Alloys; International Organization for Standardization: Geneva, Switzerland, 2019.

77. ISO/CD. 13919-2_Electron and Laser Beam Welded Joints—Guidance on Quality Levels for Imperfections-Part 2: Aluminium and Its Weldable Alloys; International Organization for Standardization: Geneva, Switzerland, 2019.

(C) 2020 by the authors. Licensee MDPI, Basel, Switzerland. This article is an open access article distributed under the terms and conditions of the Creative Commons Attribution (CC BY) license (http://creativecommons.org/licenses/by/4.0/). 